\title{
Prevalence of Intestinal Parasitic Infections among School Children in Rural Area of Vizianagaram.
}

\author{
${ }^{1}$ Dr.Supriya Panda,${ }^{2}$ Dr.U.Dharma Rao, ${ }^{3}$ Dr.K.Rama Sankaram \\ ${ }^{1}$ Professor of Microbiology, ${ }^{3}$ Professor of community medicine,Maharajah's Institute of Medical \\ Sciences,Nellimarla,Vizianagaram.Andhra Pradesh. \\ ${ }^{2}$ Research scholar, St.John's Research institute, Bangalore
}

\begin{abstract}
A total of 124 school children of Nellimarla mandal, which includes 65 females and 59 males, were screened for intestinal parasitic infections. E.histolytica and G.intestinalis were the commonest parasites isolated (each 37.7\%), followed by H.nana(11.6\%), Hookworm(8.7\%) and Strongyloides(4.3\%).Infection rate was highest in 8 years age group $(66.7 \%)$. Females (55\%) were infected more than males (40\%).
\end{abstract}

Key words: Intestinal parasites, school children

\section{Introduction:}

Intestinal parasitic infections are endemic worldwide and have been described as constituting the greatest single worldwide cause of illness and disease. Poverty,low literacy rate, poor hygiene, lack of access to potable water and hot and humid tropical climate are the factors associated with high prevalence of intestinal parasitic infections in developing countries. It is estimated that $60 \%$ of the worlds population is infected with gut parasites, which play role in morbidity. The commonest parasitic infection reported globally are Ascaris(20\%), Hook worm(18\%), Trichuris trichura(10\%) and Entamoeba histolytica(10\%) (1). In India overall prevalence varies from $13 \%$ to $68 \%$. (2). The present study aimed to estimate prevalence of intestinal parasitic infections in 6 to 9 years school children.

\section{Material And Methods:}

Material for the present study were collected from 124 (59 males \& 65 females) school children of Kondavelagada village, which is located 7 kilometers away from the Medical College belonging to Nellimarla mandal, Vizianagaram distict, from 1st December 2008 to 31st Jan 2009 after taking the informed consent from the parents and respective authority. The material was selected randomly.

STUDY GROUP: The present study group included children of 6 to 9 years and all of them belonging to low socio economic status.

SPECIMEN COLLECTION: Early morning stool specimen approximately $1 \mathrm{gm}$ was collected from each child in sterile screw capped bottles and transported to the laboratory within 2 hours.

PROCESSING: Saline\& Iodine preparation from each sample were examined under 100X, 400X magnification on the same day of collection.

The children found to be positive in microscopy were traced back and given a single dose of albendazole (400mg) and metronidazole (200mg t.i.d for 7 days) for helminthic and protozoal infections respectively. The parents of all the children and the older children were counseled regarding safe drinking water; and water \& food hygiene; and to avoid open air defecation and bare foot walk.

III.

RESULTS:

A total of 65 number of female and 59 number of male children were screened. Out of them intestinal parasitic infection was detected in $55 \%$ of female and $40 \%$ of male children. The percentage positivity were 39.5,58.1,66.7 \& 43.5 in 6 years, 7 years, 8 years and 9 years age groups respectively. E.histolytica and G.intestinalis were the commonest species isolated (each 37.7\%), followed by H.nana (11.6 \%), Hook worm $(8.7 \%)$ and S.stercoralis(4.3\%).Highest prevalence $(66.7 \%)$ was found in 8 years age group and least prevalence $(39.5 \%$ ) was found in 6 years age group. Multiple infections by 3 parasites were found in 4 cases and by 2 parasites were found in 6 cases. 
Prevalence Of Intestinal Parasitic Infections Among School Children In Rural Area Of Vizianagaram.

TABLE - 1.TOTAL ISOLATION OF PARASITES

\begin{tabular}{|l|l|l|l|}
\hline & FEMALE $(\mathbf{n}=\mathbf{6 5})$ & MALE $(\mathbf{n}=\mathbf{5 9})$ & TOTAL \\
\hline E.histolytica & 16 & 10 & $\mathbf{2 6}$ \\
\hline G.intestinalis & 13 & 13 & $\mathbf{2 6}$ \\
\hline Hook worm & 2 & 4 & $\mathbf{6}$ \\
\hline H.nana & 4 & 4 & $\mathbf{8}$ \\
\hline S.stercoralis & 2 & 1 & $\mathbf{3}$ \\
\hline TOTAL & $\mathbf{3 7}$ & $\mathbf{3 2}$ & $\mathbf{6 9}$ \\
\hline
\end{tabular}

*infection with 3 parasites were present in 4 children

*infection with 2 parasites were present in 6 children

TABLE- 2.PERCENTAGE OF ISOLATION IN DIFFERENT AGE GROUPS

\begin{tabular}{|l|l|ll|l|}
\hline AGE GROUP & $\begin{array}{l}\text { FEMALE } \\
\text { \% POSITIVE }\end{array}$ & $\begin{array}{l}\text { MALE - } \\
\text { POSITIVE }\end{array}$ & $\begin{array}{l}\text { TOTAL } \\
\text { \% POSITIVE }\end{array}$ \\
\hline 6 YEARS & 55 & 26.1 & 39.5 \\
\hline 7 YEARS & 50 & 66.7 & 58.1 \\
\hline 8 YEARS & 85.7 & 46.2 & 66.7 \\
\hline 9 YEARS & 40 & 50 & 43.5 \\
\hline
\end{tabular}

TABLE -3

\begin{tabular}{|l|l|l|l|}
\hline $\begin{array}{l}\text { EDUCATION OF HEAD OF THE } \\
\text { FAMILY }\end{array}$ & WEIGHTAGE & $\begin{array}{l}\text { NO. } \\
\text { FAMILIES }\end{array}$ & $\begin{array}{l}\text { PERCENTAGE } \\
(\boldsymbol{\%})\end{array}$ \\
\hline Illiterate & 1 & 78 & 72.2 \\
\hline Primary school & 2 & 19 & 17.6 \\
\hline Middle school & 3 & 7 & 6.5 \\
\hline High school & 4 & 4 & 3.7 \\
\hline TOTAL NO. OF FAMILIES & \multicolumn{2}{|l}{} \\
\hline
\end{tabular}

TABLE- 4

\begin{tabular}{|l|l|l|}
\hline $\begin{array}{l}\text { OCCUPATION OF HEAD OF THE } \\
\text { FAMILY }\end{array}$ & WEIGHTAGE & $\begin{array}{l}\text { NO. } \\
\text { FAMILIES }\end{array}$ \\
\hline Unemployed & 1 & 24 \\
\hline Unskilled daily laborers & 2 & 62 \\
\hline Semiskilled daily laborers & 3 & 22 \\
\hline
\end{tabular}

TABLE- 5

\begin{tabular}{|l|l|l|}
\hline $\begin{array}{l}\text { PERCAPITA INCOME OF THE } \\
\text { FAMILY PER MONTH }\end{array}$ & WEIGHTAGE & $\begin{array}{l}\text { NO. } \\
\text { FAMILIES }\end{array}$ \\
\hline Rs/- $150-249$ & 1 & 52 \\
\hline Rs/- $250-499$ & 2 & 37 \\
\hline Rs/- 500-999 & 3 & 19 \\
\hline
\end{tabular}

- Among all the 108 families 89 families $(82.4 \%)$ are in the below poverty line (socio economic status scale $<5), 19$ families (17.6\%) are in upper lower poverty line.

-• All the families (108 families) are of low socio economic status $\&$ holding white ration cards.

TABLE- 6

\begin{tabular}{|ll|lll|}
\hline $\begin{array}{l}\text { NO. OF CHILDREN USING WATER } \\
\text { CONTAINER WITH TAP. }\end{array}$ & $\begin{array}{l}\text { NO. OF CHILDREN USING } \\
\text { CONTAINER WITH OUT TAP }\end{array}$ & WATER \\
\hline 0 & 124 & \\
\hline
\end{tabular}

TABLE- 7

\begin{tabular}{|l|l|l|}
\hline & $\begin{array}{l}\text { NO. OF CHILDREN } \\
\text { USING CHAPPALS }\end{array}$ & $\begin{array}{l}\text { NO. OF CHILDREN WITH } \\
\text { BARE FOOT }\end{array}$ \\
\hline MALE NUMBER & 19 & 39 \\
\hline FEMALE NUMBER & 04 & 62 \\
\hline
\end{tabular}




\begin{tabular}{|l|l|}
\multicolumn{2}{l}{ TABLE- 8} \\
\hline MOTHER EDUCATION. & NO. OF CHILDREN \\
\hline ILLETERATE & 97 \\
\hline PRIMARY SCHOOLING & 05 \\
\hline MIDDLE SCHOOL & 03 \\
\hline TOTAL NO. & $\mathbf{1 0 5}$ \\
\hline
\end{tabular}

TABLE-9

\begin{tabular}{|l|lrl|l|r|}
\hline NO. OF CHILDREN USING TOILET & NO. OF CHILDREN USING HAND FOR \\
PAPERS TO CLEAN ANAL AREA AFTER & CLEANING ANAL & AREA & AFTER \\
DEFECATION. & DEFECATION. & & \\
\hline 0 & 124 & & \\
\hline
\end{tabular}

TABLE-10

\begin{tabular}{|l|lll|}
\hline $\begin{array}{l}\text { NO. OF CHILDREN USING SANITARY } \\
\text { LATRINES FOR DEFECATION. }\end{array}$ & $\begin{array}{l}\text { NO. OF CHILDREN DOING OPEN AIR } \\
\text { DEFECATION. }\end{array}$ & \\
\hline 0 & 124 & & \\
\hline
\end{tabular}

- TABLE-11: Only $32.2 \%$ of males and $6.2 \%$ of females are using chappals.

- TABLE-12: $97.4 \%$ of mothers are illiterates.

- All 124 children doing open-air defecation, using hands for cleaning the anal area after defecation.

\section{Discussion:}

In this study, half of school children were infected with intestinal parasites. E.histolytica and G.intestinalis infections were more common than helminthic infection. This is as per with other studies $(3,4,5)$. Both can be transmitted orally by drinking infected water and both are environmental contaminants of the water supply. Defecation occurs in the surrounding fields in the villages by the villagers and the stools are exposed to scavenging animals and the drying effects of the sun and wind. Animals and wind have been proposed as sources of water supply contamination, and of direct infection (6). All 4 cases of triple infections have both Hookworm and Strongyloides. This can be attributed to walking bare foot as these infections result from penetration of the skin by filariform larvae. Infection rate was highest in 8 years age group. Infection rate was more in female than male, which can be due to bare foot walk, which was more found in females. In this current study most of the complaints by the study population were not related with the intestinal parasitic infection. In this study infection by Ascaris lumbricoidis was not detected in contrast to studies from Visakhapatnam and other parts of India where A.lumbricoides was the most common infection $(7,8)$. The relation between a child's health and the mother's education is well known. Health indicators of children whose mother's education level is lower are always worse which is consistent in the present study. Cleaning of the anal area by washing with the hand carries more risk of parasitic transmission than use of toilet paper.

\section{Conclusion:}

Among 124 children screened, E.histolytica and G.intestinalis were the commonest parasites isolated (each $37.7 \%$ ), followed by H.nana(11.6\%), Hookworm(8.7\%) and Strongyloides(4.3\%). 55.6\% of children were found to be positive for intestinal parasites. Infection rate was highest in 8 years age group(66.7\%). Females $(55 \%)$ were infected more than males $(40 \%)$. This study shows that, Intestinal parasitic infection is a major public health problem in rural areas of India. Poverty, low literacy rate, open-air defecation, washing of the anal area by hand after defecation and rural residence are the significant associations. Interventions including health education and personal hygiene to the students and the parents, especially to the mothers are required. The villagers should be counseled to use sanitary latrines provided by the Government. There is a need to promote mass scale deworming and health promotion campaigns to create awareness about health and hygiene

\section{References:}

[1] WHO report 1987

[2] G.kang et.al.,Tropical medicine and international health, volume-3 no.1,page-72-75,year 1998.

[3] Pinar Okyay et.al.,BMC, Public health, 4:64, 2004.

[4] Sehgal R Gogulamudi V. Reddy Jaco J. Verweij Atluri V. Subba Rao. Prevalence of intestinal parasitic infections among school children and pregnant women in a low socio-economic area, Chandigarh, North India.

[5] Reviews in infection .Research Article.2010;1(2):100-103.

[6] Atul Aher, Sanjeev Kulkarni. Prevalence of intestinal parasites inschool going schildren in a rural community.International J of biomedical rearch.2011;2(12):605-607

[7] Bindinger et.al., Aspects of intestinal parasitism in villagers from rural peninsular India, parasitology, 87, page 299-306,1981.

[8] I.Paul et.al., Indian journal of pediatrics, volume - 66, no.5, page-669-673, year 1999.

[9] S. Awasthi and V.K. Pande Prevalence of malnutrition and intestinal parasites in preschool slum children in Lucknow.Indian Paediatrics.1997;34:599-605. 